\title{
The Connection between Low Income, Weak Labour Force Attachment and Poor Health
}

\author{
Myriam Fortin \\ Senior Researcher \\ Social Policy Directorate \\ Human Resources and Skills Development Canada \\ Gatineau, Quebec, Canada \\ E-mail: $\underline{\text { myriam.fortin } @ \text { hrsdc-rhdcc.gc.ca }}$
}

\begin{abstract}
Using 1994-2004 data from the National Population Health Survey, this paper sheds light on the health situation of working-age Canadians and tests the connection between low income, weak labour force attachment and poor health using logistic regressions. Results indicate that persistently poor or weakly employed Canadians are in much poorer health than other Canadians, and that being persistently poor increases the probability of experiencing deterioration in health as much as being in poor health increases the probability of becoming poor, but that being persistently unemployed has an even stronger impact on health status.
\end{abstract}

Key Words: Health, low income, poor, labour market, Canadians 


\section{Résumé}

À l'aide des données de l'enquête nationale sur la santé de la population pour la période allant de 1994 à 2004, cet article documente l'état de santé des canadiens en âge de travailler et estime, grâce à la régression logistique, la force des liens entre faible revenu, faible effort de travail et mauvaise santé. Les résultats obtenus indiquent que les Canadiens qui sont, de façon persistante, pauvres ou faiblement actifs sur le marché du travail sont en très mauvaise santé comparé aux autres canadiens, que la pauvreté persistante accroît la probabilité d'une détérioration de l'état de santé dans la même mesure que d'être en mauvaise santé accroît la probabilité de devenir pauvre, mais que de travailler peu ou proue, de façon persistante, a un effet encore plus fort sur la santé.

Mots clés: Santé, faible revenu, pauvre, marché du travail, Canadiens

\section{Introduction}

There is a wealth of studies on the relationship between low income and poor health (for example, see Phipps 2003; Raphael 2001, 2002, 2003, 2007, Mullhaly et al. 2004) for an overview of the research; Williamson and Reuter (1999) for the impacts of poverty on health). Recently, Wilkins et al. 2008: 30, examining mortality in Canada from 1991 to 2001, also discovered that "The inter-quintile difference (Q5-Q1) in life expectancy was 6.8 years for men, and 4.3 years for women... Only $51 \%$ of men in the poorest quintile were expected to survive to age 75 , compared with $72 \%$ of those in the richest quintile. The corresponding figures for women were $72 \%$ versus $84 \%$."

Studies on poverty have found, however, that not all low-income Canadians are 'equal'. For example, while the so-called working poor (i.e. those who have a strong attachment to the labour market) have a better chance of escaping poverty than other poor Canadians, they often do not enjoy the same health benefits (Fleury, Fortin and Luong 2005; Fleury and Fortin 2006). Rural Canadians generally have worse health outcomes than urban Canadians (Desmeules et al. 2006). They also have to travel longer distances to see a physician, and the problem is greater for low-income families ( $\mathrm{Ng}$, Edward et al. 1996; Pong and Pitblado 2005). It is also true that long-duration poverty has greater negative health effects than occasional episodes of poverty (Phipps 2003). Investigating various health outcomes among sub-groups of poor, Fortin, 
The Connection between Low Income,

Weak Labour Force Attachment and Poor Health

(2008) found that the largest differences would likely be between the working poor and the welfare poor, and that these were often times larger than the differences between poor and non-poor. This indicates that lack of attachment to the labour market, even more than low income, may be associated with poor health. This is one of the questions that the present study investigates. The other question that is explored is the direction of the connection between poor health and low socio-economic status, i.e. does poor health lead to reduced economic circumstances or is the reverse generally truer? The answer to that question is important both because it has serious policy implications and because few papers have studied the causal link between low income and poor health using Canadian data while none explored the connection between weak work effort and poor health (see Wolfson et al. 1993, Buckley et al. 2003; Orpana et al. 2007).

\section{Objectives of the Study}

This paper summarizes results from a larger study. First, using data from the first six cycles of Statistics Canada's National Population Health Survey (NPHS), it investigates differences in the health outcomes, access to, use of and satisfaction with health care services of groups of working-age Canadians according to their income and employment status. This is then followed by a logistic regression analysis to assess the direction and strength of the connection between low income, weak labour force attachment and poor health.

Research has paid little attention to the health situation of poor workingage Canadians ${ }^{1}$. The present paper fills a gap in our understanding of the relationship between poverty and poor health. This is important because "In contrast to other nations where research and policy concern with poverty and health has a long-standing history such as the UK, few Canadian researchers explicitly focus on the health of people living in poverty" (Raphael 2007: 228). A scan of the literature also shows that with the exception of two reports by provincial health departments (Québec 2007; Toronto 2008), very little recent Canadian research has documented the consequences of living in poverty. Most research on poverty has, so far, focused on the determinants of low income and on the reasons explaining entry into or exit from low income (for example, see Fleury, Fortin and Luong 2005; Fortin 2005; Fleury and Fortin 2006; Human Resources and Social Development Canada 2006; Fleury 2007; Kapsalis and Tourigny, forthcoming). 


\section{Methodology}

\section{Data Source}

The data used to conduct this research are from cycles one to six of the NPHS and cover years 1994-95 to 2004-05. The NPHS is designed to collect "longitudinal" information on the health of the Canadian population and related socio-demographic information. The target population of the NPHS Household component includes household residents in the ten Canadian provinces in 1994/1995 excluding persons living on Indian Reserves and Crown Lands, residents of health institutions, full-time members of the Canadian Forces Bases and some remote areas in Ontario and Quebec. The NPHS longitudinal sample included 17,276 persons from all ages in 1994. In 2004, 11,593 respondents had a full response. These same persons are interviewed every two years over a period of 18 years.

\section{Target Population}

Only those who had a full response in the first six cycles of the NPHS were investigated in this study. Descriptive statistics focus on working-age Canadians, i.e. Canadians who were 18 to 54 years old in 1994. These individuals were divided into groups according to their income and employment status. The target populations in logistic regressions vary by scenario. See Table 1 for details on each of the populations investigated.

\section{Analytical Techniques}

For the descriptive part of this research, proportions of sub-groups of workingage Canadians who had various socio-demographic or health characteristics were tabulated. All estimates were weighted to represent the Canadian household population in 1994. To account for the survey design effect of the NPHS, standard errors, coefficients of variation, and $95 \%$ confidence intervals were estimated using the bootstrap technique (as per the methodology developed by Piérard et al. 2003). Differences between estimates were tested for statistical significance, which was established at the 0.05 level. $^{2}$

In the second part of the study, logistic regression is applied to test the connection between low income, weak labour force attachment and poor health. Table 1 summarizes the four scenarios that were investigated in this paper. The Appendix table provides detailed information on how variables were defined in regression analyses.

Logistic regression assesses the strength (and sign) of associations between a dependent variable and explanatory variables. The dependent variable $(Y)$ that we seek to model is a dichotomous variable set at 1 if the individual was 
The Connection between Low Income,

Weak Labour Force Attachment and Poor Health

\begin{tabular}{|c|c|c|c|c|}
\hline 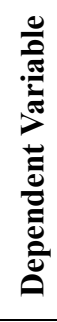 & 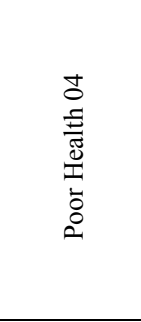 & $\begin{array}{l}\text { to } \\
\text { ŏ } \\
0\end{array}$ & 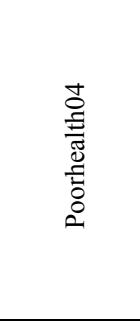 & 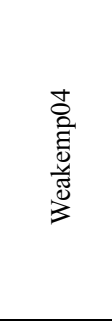 \\
\hline 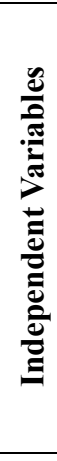 & 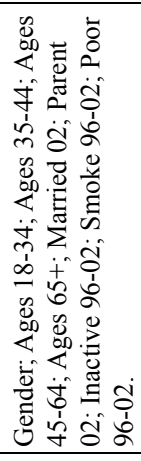 & 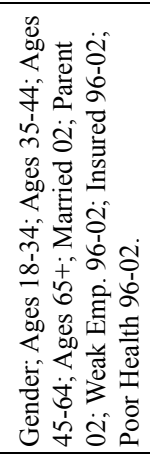 & 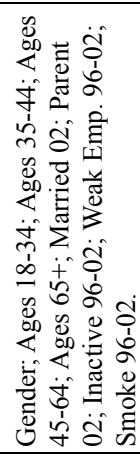 & 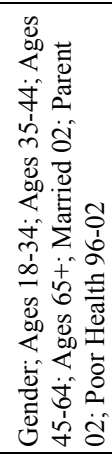 \\
\hline 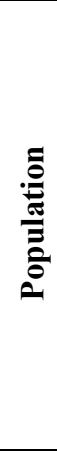 & 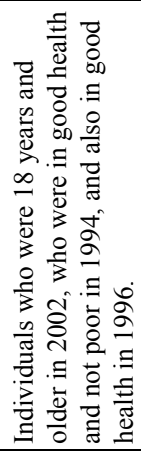 & 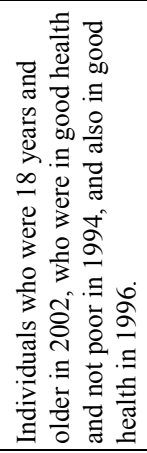 & 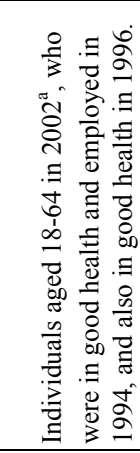 & 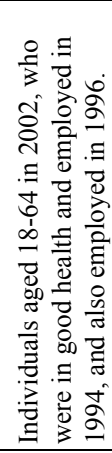 \\
\hline 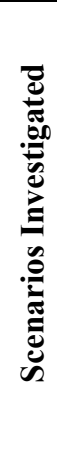 & 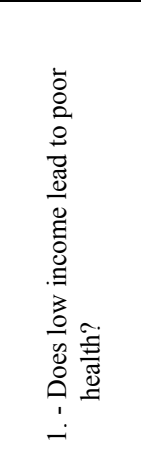 & 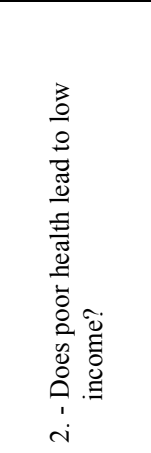 & 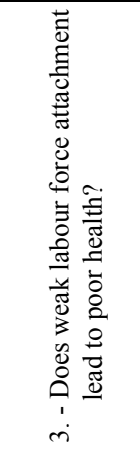 & 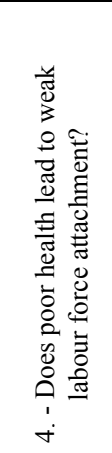 \\
\hline
\end{tabular}

CSP 2010, 37.1-2: 25-52 
poor in 2004 or weakly attached to the labour force or in poor health, depending on the scenario, and at 0 if the individual was not.

\section{Controlling for Reverse Causality}

Restrictions were imposed on the samples to avoid, as much as possible, reverse causality when conducting regressions (see Table 1 Population column for restrictions imposed). What do we mean by reverse causality? Let us assume that we follow individuals over the entire period available i.e. we test if their income status in 1994 is a good predictor of their health status in 2004. The problem with this scenario is that we know nothing of the income and health status of those individuals prior to 1994, i.e. we do not know if the fact that a person was poor in 1994 might not be due to bad health prior to 1994, in which case we would be testing if poor health leads to poor health. For example, a person who had a heart attack in 1990 and had to stop working for a few years could end up being in low income in 1994 because of a health problem. This person could, nevertheless, report being in good health in 1994 if one's condition improved over time. Obviously, this person would have a higher likelihood of becoming sick than others over 1996 to 2004 not because of one's income status in 1994 but because of a heart condition. Limiting the sample to individuals who were in good health and not poor prior to the period of observation reduces the likelihood that a health or income selection bias is present. The same logic applies to models testing the causal connection between weak labour force attachment and poor health.

\section{Proxy for Health Status}

Self-rated health is used as a proxy for general health status. This variable has been shown to have strong predictive validity in regard to future changes in such health outcomes as disability, illness and hospitalization across virtually all age groups in the population. As well, this variable has predictive power in terms of mortality risk; and has concurrent and predictive validity with many other health measures (Buckley et al. 2003; Orpana et al. 2007: 42) 
The Connection between Low Income,

Weak Labour Force Attachment and Poor Health

\section{Descriptive Results}

\section{Profiles of Vulnerable Working-age Canadians}

Of all Canadians who were of working-age in 1994, 341,200 experienced persistent poverty over 1994 to 2004 while 7,393,500 were never poor (Table 2). In comparison, 10,088,900 were significantly employed in all cycles while 528,500 were in none.

Working-age Canadians who were persistently poor have a profile that is quite different from that of Canadians who were never poor. In 1994, the former were much more likely than the latter to be female, to live in Quebec, to be unattached or a lone parent, and not to have completed high school. The same could be said comparing weakly employed vs. significantly employed individuals, except that the former were also much older than the latter, and that more similar proportions of both groups were part of a couple with children. Overall, these results indicate that being a woman, a lone parent and having little education are characteristics that are strongly associated with persistent poverty or weak attachment to the labour market.

One might think that similarities between persistently poor and weakly employed working-age Canadians were to be expected, considering the strong links between labour force status and income. However, this study found that only $28 \%$ of those who were weakly employed in all cycles experienced persistent poverty over 1994 to 2004 while $37 \%$ of those who were persistently poor were weakly employed in all cycles.

Persistently poor and weakly employed working-age Canadians do not only have similar socio-economic profiles, they are also much more likely than those with higher incomes or more stable employment to have poor health outcomes (Table 3). The following sections present some of the most striking differences between the groups.

Prevalence of Illnesses and Perceived Health. Over 1994 to 2004, the prevalence of fair or poor self-rated health was 40 percentage points (pp) higher among the persistently poor or weakly employed than among those with higher incomes or more stable employment. The prevalence of heart disease was $14 \mathrm{pp}$ higher among those who were persistently weakly employed than among those who were employed significantly. There were no significant differences between the groups with respect to the prevalence of cancer.

Mental Health. The prevalence of depressions diagnosed by a health professional was over $22 \mathrm{pp}$ higher among the persistently poor or weakly employed than among those with higher incomes or more stable employment.

CSP 2010, 37.1-2: 25-52 
Table 2

Demographic Characteristics and Education Profiles of Working-age Canadians in 1994

\begin{tabular}{|c|c|c|c|c|}
\hline Variables & $\begin{array}{l}\text { Poor in all Cycles } \\
\text { over 1994-2004 }\end{array}$ & $\begin{array}{l}\text { Never Poor over } \\
1994 \text { to } 2004\end{array}$ & $\begin{array}{c}\text { Significantly } \\
\text { Employed in all } \\
\text { Cycles between } \\
1994 \text { and } 2004\end{array}$ & $\begin{array}{l}\text { Weakly Employed } \\
\text { in all Cycles } \\
\text { between } 1994 \text { and } \\
2004\end{array}$ \\
\hline Individuals Aged 18 to 54 in 1994 & 341,200 & $7,393,500$ & $10,088,900$ & 528,500 \\
\hline \multicolumn{5}{|l|}{ Gender } \\
\hline Male & $24.3 \%$ & $52.6 \%$ & $57.6 \%$ & $20.6 \%$ \\
\hline Female & $75.7 \%$ & $47.4 \%$ & $42.4 \%$ & $79.4 \%$ \\
\hline \multicolumn{5}{|l|}{ Age } \\
\hline $18-24$ & $* * *$ & $9.8 \%$ & $14.9 \%$ & $* * *$ \\
\hline $25-34$ & $38.7 \%$ & $33.5 \%$ & $32.2 \%$ & $16.9 \%$ \\
\hline $35-44$ & $32.1 \%$ & $34.4 \%$ & $36.3 \%$ & $24.6 \%$ \\
\hline $45-54$ & $21.4 \%$ & $22.2 \%$ & $16.7 \%$ & $55.6 \%$ \\
\hline \multicolumn{5}{|l|}{ Province of Residence } \\
\hline $\begin{array}{l}\text { Atlantic Provinces } \\
\text { (NFL, PEI, NB or NS) }\end{array}$ & $12.2 \%$ & $8.2 \%$ & $7.8 \%$ & $13.2 \%$ \\
\hline Quebec & $42.3 \%$ & $23.8 \%$ & $24.0 \%$ & $31.9 \%$ \\
\hline Ontario & $* * *$ & $40.2 \%$ & $38.0 \%$ & $35.4 \%$ \\
\hline Manitoba, Saskatchewan or Alberta & $11.7 \%$ & $16.0 \%$ & $17.5 \%$ & $8.9 \%$ \\
\hline $\mathrm{BC}$ & $* * *$ & $11.8 \%$ & $12.7 \%$ & $* * *$ \\
\hline \multicolumn{5}{|l|}{ Family type } \\
\hline Unattached & $24.6 \%$ & $10.6 \%$ & $11.6 \%$ & $16.3 \%$ \\
\hline Couple without children & $* * *$ & $19.7 \%$ & $15.8 \%$ & $19.5 \%$ \\
\hline Couple with children & $34.7 \%$ & $63.1 \%$ & $63.8 \%$ & $47.6 \%$ \\
\hline Lone parent family & $33.7 \%$ & $5.3 \%$ & $7.1 \%$ & $16.5 \%$ \\
\hline Other family type & $* * *$ & $* * *$ & $0.9 \%$ & $* * *$ \\
\hline \multicolumn{5}{|l|}{ Other Demographic Characteristics } \\
\hline $\begin{array}{l}\text { Recent immigrant } \\
\text { (less than } 10 \text { years in Canada) }\end{array}$ & $* * *$ & $2.7 \%$ & $4.7 \%$ & $* * *$ \\
\hline Aboriginal person living off reserve & $* * *$ & $* * *$ & $* * *$ & $* * *$ \\
\hline Has work limitations & $* * *$ & $4.9 \%$ & $4.8 \%$ & $* * *$ \\
\hline \multicolumn{5}{|l|}{ Highest Level of Education Obtained } \\
\hline Less than a high school diploma & $44.7 \%$ & $10.5 \%$ & $11.3 \%$ & $44.4 \%$ \\
\hline High school diploma & $* * *$ & $18.1 \%$ & $17.8 \%$ & $16.2 \%$ \\
\hline More than a high-school diploma & $32.9 \%$ & $46.5 \%$ & $49.4 \%$ & $33.4 \%$ \\
\hline University degree & $* * *$ & $24.8 \%$ & $21.4 \%$ & $6.1 \%$ \\
\hline
\end{tabular}

*** not a sufficient number of observations. 
The Connection between Low Income, Weak Labour Force Attachment and Poor Health

Table 3

Prevalence of Various Health Outcomes over 1994 to 2004 for Groups of Working Age Canadians

\begin{tabular}{|c|c|c|c|c|}
\hline Variables & $\begin{array}{l}\text { Never Poor over } \\
1994-2004\end{array}$ & $\begin{array}{c}\text { Persistently Poor over } \\
\text { 1994-2004 }\end{array}$ & $\begin{array}{c}\text { Significantly employed } \\
\text { in all cycles over } \\
1994-2004\end{array}$ & $\begin{array}{l}\text { Weakly employed in } \\
\text { all cycles over } \\
1994-2004\end{array}$ \\
\hline \multicolumn{5}{|l|}{ Incidence of illnesses and perceived health: } \\
\hline Ever had heart disease & $5.5 \%$ & $\begin{array}{c}8.7 \% \\
(\text { poor } 3+c)\end{array}$ & $4.9 \%$ & $18.5 \%$ \\
\hline Ever had cancer & $3.8 \%$ & $\begin{array}{c}5.5 \% \\
(\text { poor } 3+c)\end{array}$ & $2.5 \%$ & $* * *$ \\
\hline $\begin{array}{c}\text { Fair or poor self-rated health } \\
(1+\text { cycle })\end{array}$ & $15.8 \%$ & $56.5 \%$ & $14.6 \%$ & $52.5 \%$ \\
\hline Stressed (1+ cycle) & $49.6 \%$ & $58.1 \%$ & $51.6 \%$ & $40.9 \%$ \\
\hline Decrease in HUI3 score & $33.4 \%$ & $46.9 \%$ & $33.4 \%$ & $48.0 \%$ \\
\hline \multicolumn{5}{|l|}{ Mental health: } \\
\hline $\begin{array}{l}\text { Mental Distress (Mean K10 score 1994-2004, } \\
\text { Higher scores indicate more distress) }\end{array}$ & 2.50 & 5.52 & 2.59 & 4.15 \\
\hline Felt like a failure (1+cycle) & $2.6 \%$ & $\begin{array}{c}9.2 \% \\
(\text { poor } 3+c)\end{array}$ & $3.1 \%$ & $* * *$ \\
\hline $\begin{array}{l}\text { Ever had depression diagnosed by health } \\
\text { professional }\end{array}$ & $12.0 \%$ & $34.4 \%$ & $12.3 \%$ & $36.4 \%$ \\
\hline \multicolumn{5}{|l|}{ Childhood traumas: } \\
\hline Hospitalized for more than 2 weeks as a child & $15.0 \%$ & $30.9 \%$ & $14.2 \%$ & $21.3 \%$ \\
\hline Scared as a child & $20.4 \%$ & $32.1 \%$ & $19.9 \%$ & $31.5 \%$ \\
\hline $\begin{array}{l}\text { Sent away for doing something wrong as a } \\
\text { child }\end{array}$ & $1.7 \%$ & $4.5 \%$ & $1.8 \%$ & $* * *$ \\
\hline $\begin{array}{l}\text { Parents used drugs or alcohol when was a } \\
\text { child }\end{array}$ & $16.1 \%$ & $28.4 \%$ & $15.2 \%$ & $19.0 \%$ \\
\hline Abused as a child & $7.5 \%$ & $21.9 \%$ & $6.7 \%$ & $12.9 \%$ \\
\hline \multicolumn{5}{|l|}{ Disabilities: } \\
\hline $\begin{array}{l}\text { Health condition reducing activity at home } \\
(1+\text { cycle })\end{array}$ & $21.6 \%$ & $44.5 \%$ & $20.5 \%$ & $61.1 \%$ \\
\hline Work limitations $(1+$ cycle $)$ & $19.0 \%$ & $28.8 \%$ & $20.3 \%$ & $22.5 \%$ \\
\hline $\begin{array}{l}\text { Injuries due to rep. strains that limited } \\
\text { normal activities }(1+\text { cycle })\end{array}$ & $39.0 \%$ & $31.6 \%$ & $39.1 \%$ & $28.9 \%$ \\
\hline \multicolumn{5}{|l|}{ Job stress: } \\
\hline Not satisfied with job $(1+$ cycle $)$ & $16.5 \%$ & $\begin{array}{c}29.1 \% \\
(\text { poor } 3+c)\end{array}$ & $20.4 \%$ & $\mathbf{n} / \mathbf{a}$ \\
\hline
\end{tabular}

${ }^{\text {a }}$ When this information is not available for the persistently poor it is provided, as a proxy, for those who were poor in at least three cycles over 1994 to 2004. This is denoted as " $3+c$ " in the table.

${ }^{b}$ The $\mathrm{K} 10$ is a scale measuring non-spccific psychological distress developed by Kessler and Mroczek in 1992. This scale consists of ten questions about non-specific psychological distress and seeks to measure the level of current anxiety and depressive symptoms that a person may have experienced in the four weeks or month prior to the interview (Australian Bureau of Statistics, 2003). 
Table 3 (Continued)

Prevalence of Various Health Outcomes over 1994 to 2004 for Groups of Working Age Canadians

\begin{tabular}{|c|c|c|c|c|}
\hline Variables & $\begin{array}{l}\text { Never Poor over } \\
1994-2004\end{array}$ & $\begin{array}{c}\text { Persistently Poor over } \\
\text { 1994-2004 }\end{array}$ & $\begin{array}{c}\text { Significantly employed } \\
\text { in all cycles over } \\
1994-2004\end{array}$ & $\begin{array}{l}\text { Weakly employed in } \\
\text { all cycles over } \\
1994-2004\end{array}$ \\
\hline \multicolumn{5}{|l|}{ Food insecurity: } \\
\hline $\begin{array}{l}\text { Lacked food or money to buy it in } 1996 \text { or in } \\
1998\end{array}$ & $1 \%-3 \%$ & $35 \%-60 \%$ & $2 \%-12 \%$ & $12 \%-21 \%$ \\
\hline \multicolumn{5}{|l|}{ Modifiable Behaviours: } \\
\hline Obese ( $3+$ cycles) & $17.5 \%$ & $23.0 \%$ & $16.3 \%$ & $28.9 \%$ \\
\hline Physically inactive (3+ cycles) & $61.5 \%$ & $75.5 \%$ & $64.3 \%$ & $70.6 \%$ \\
\hline Reg. smoker (3+ cycles) & $23.8 \%$ & $44.1 \%$ & $25.5 \%$ & $30.4 \%$ \\
\hline Reg. drinker (3+ cycles) & $78.9 \%$ & $39.7 \%$ & $76.8 \%$ & $40.4 \%$ \\
\hline Mean no. drinks p. wk (1994-2004) & 4.70 & 3.99 & 4.72 & 3.19 \\
\hline \multicolumn{5}{|l|}{ Other behaviours: } \\
\hline $\begin{array}{l}\text { Slept, on average, less than } 6 \mathrm{hrs} \text { per night } \\
\text { over 1994-2004 }\end{array}$ & $16.7 \%$ & $31.4 \%$ & $18.5 \%$ & $28.8 \%$ \\
\hline Had leisure activities in all cycles & $73.9 \%$ & $\begin{array}{c}58.3 \% \\
(\text { poor } 3+c)\end{array}$ & $69.2 \%$ & $53.3 \%$ \\
\hline \multicolumn{5}{|l|}{ Preventative services: } \\
\hline Physical check-up every 3 years & $88.9 \%$ & $\begin{array}{c}\mathbf{8 8 . 0} \% \\
(\text { poor } 3+c)\end{array}$ & $87.2 \%$ & $* * *$ \\
\hline No dental exam over 1994-1996 & $11.1 \%$ & $\begin{array}{c}24.7 \% \\
(\text { poor } 3+c)\end{array}$ & $12.7 \%$ & $24.6 \%$ \\
\hline \multicolumn{5}{|l|}{ Health care (HC) services: } \\
\hline Had family doctor in all cycles & $67.8 \%$ & $64.5 \%$ & $62.8 \%$ & $78.4 \%$ \\
\hline Received HC services & $83.9 \%$ & $81.3 \%$ & $79.5 \%$ & $86.6 \%$ \\
\hline Unmet HC needs $(1+$ cycle) & $26.4 \%$ & $44.5 \%$ & $27.4 \%$ & $36.8 \%$ \\
\hline $\begin{array}{l}\text { Overnight patient in a medical institution (1+ } \\
\text { cycle) }\end{array}$ & $28.8 \%$ & $44.7 \%$ & $25.4 \%$ & $51.1 \%$ \\
\hline $\begin{array}{l}\text { Neighbourhood: too noisy or polluted (1+ } \\
\text { cycle) }\end{array}$ & $18.2 \%$ & $39.0 \%$ & $19.7 \%$ & $22.3 \%$ \\
\hline \multicolumn{5}{|l|}{ Insurance coverage in 2002: } \\
\hline $\begin{array}{l}\text { Insured for prescription medication, dental } \\
\text { expenses, eye glasses }\end{array}$ & $70 \%-90 \%$ & $50 \%-90 \%$ & $63 \%-85 \%$ & $54 \%-80 \%$ \\
\hline Insured for hospital charges & $80.6 \%$ & $32.8 \%$ & $74.4 \%$ & $44.1 \%$ \\
\hline
\end{tabular}

*** Insufficient number of observations. 
The Connection between Low Income,

Weak Labour Force Attachment and Poor Health

Traumas Experienced during Childhood. The prevalence of traumas experienced during childhood such as being hospitalized for long periods of time, or being so scared as to remember it years later, or seeing one's parents use drugs or alcohol, and being abused by someone close was 10 to 15 pp higher among the persistently poor than among those who were never poor.

Disabilities. The prevalence of health conditions reducing activity at home was 20 to $40 \mathrm{pp}$ higher among persistently poor or weakly employed persons than among those with higher incomes or more stable employment.

Job Stress. The proportion of working-age Canadians who were dissatisfied with their jobs was close to $15 \mathrm{pp}$ higher among the persistently poor than among those who were never poor.

Food Insecurity. The proportion of working-age Canadians who did not have enough food or money to buy it in 1996 or in 1998 was 35 to 60 pp higher among the persistently poor than among those who were never poor.

Modifiable Health Behaviours. The prevalence of persistent obesity was close to $13 \mathrm{pp}$ higher among those who were persistently weakly employed than among those who were significantly employed in all cycles. The prevalence of regular smoking, lack of physical or leisure activities, and sleep deprivation was 14 to $20 \mathrm{pp}$ higher among the persistently poor than among those who were never poor.

Preventative Services. In 1996, similar proportions of all groups (close to 90\%) reported having had a physical check-up at least every three years. However, the proportion of individuals reporting that they did not have a dental exam over the past three years was twice as high among the persistently poor or weakly employed than among those with higher incomes or more stable employment $(24 \%$ vs. $12 \%)$.

Health Care Services. Over $60 \%$ of all groups reported having a family doctor in all cycles, although those who were persistently weakly employed were the most likely to say so. High and similar proportions of all groups ( $80 \%$ or more) also reported receiving any health care services in at least one cycle over 1994 to 2004. However, the proportion of individuals reporting unmet health care needs was 10 to $20 \mathrm{pp}$ higher among the persistently poor than among those with higher incomes. Furthermore, the proportion of individuals that reported overnight stays in a medical institution was 16 to 25 pp higher among the weakly employed than among those with more stable employment.

CSP 2010, 37.1-2: 25-52 
Neighbourhood Satisfaction. The proportion of working-age Canadians who reported living in neighbourhoods that were too noisy or polluted at least once over 1994 to 2004 was over 20 pp higher among the persistently poor than among those who were never poor.

Private Health Insurance Coverage. In 2002, the proportion of working-age Canadians who reported being covered for prescription medication, dental expenses and eye glasses was 10 to $20 \mathrm{pp}$ lower among those who were persistently poor or weakly employed than among those with higher incomes or more stable employment. Furthermore, the proportion that reported not being covered for hospital charges was 30 to $48 \mathrm{pp}$ higher among the persistently poor or weakly employed. This last result has to be interpreted with caution as individuals whose main source of income is welfare may not always realize that they are covered through provincial social assistance programs. Also, weakly employed individuals who live with a worker may not realize that their spouses' insurance plan protects them. These factors could lead to under-reporting of insurance coverage for the persistently poor or weakly employed.

This overview indicates that working-age Canadians who are persistently poor or weakly employed have far worse health conditions than those who have higher incomes or more stable employment. However, are their socio-economic circumstances the precursor to their poor health or its consequence? This question, which has important policy implications is explored below.

\section{Low Income, Weak Labour Force Attachment and Poor Health}

The present study brings new light to the causality issue by investigating the strength and direction of the connection between low income, weak labour force attachment and poor health. Compared to previous studies (e.g. Buckley et al. 2003; Orpana et al. 2007; Wolfson 1993) it uses more extensive data and examines a larger set of health variables (six cycles of NPHS data vs. three and two, respectively). It also looks at the reciprocal relationship between poverty and health - i.e., whether poor health leads to low income or weak labour force attachment; and whether persistent poverty/weak labour force attachment leads to poor health among poor and non-poor Canadians.

Poor health is expected to lead to weak labour force attachment and poverty. Individuals who are in poor health have weaker chances than others to find or to keep a job. However, poor personal health does not automatically lead to poverty. This will only happen if a person's earnings are so important to 
The Connection between Low Income,

Weak Labour Force Attachment and Poor Health

family income that losing part or all of it will compromise the financial situation of the entire family (unattached individuals, lone parents, or single-earner couples are especially at risk).

It is assumed that there is a close connection between low income and poor health. Canadians that have limited financial resources are more likely than others to go hungry or to eat less nutritious food, to live in overcrowded, noisy or unhealthy housing, to be stressed - all factors that negatively affect health. The association between weak labour force attachment and poor health is less obvious. Why should a person who is unemployed be in poorer health than one's more active counterparts? One likely explanation is that unemployed individuals face a much higher risk of poverty and therefore, poor health consequences. Another possible explanation is the lack of sense of belonging to a 'community' by the unemployed. Being employed usually means having regular access to a large network of individuals, i.e. to potentially benefit from more social support. Working also means getting recognition for what one does. Individuals who are unemployed, especially if it is for prolonged periods of time, may suffer from a lack of self-esteem which can result in a higher likelihood of mental illness. In other words, weak labour force attachment can lead to poor health in more ways than does low income alone.

\section{Low Income and Poor Health}

The following explanatory variables included in the logistic regression were to test whether low income leads to poor health: gender, age, marital status, parental status, level of physical activity, smoker or not, and income status. The following variables were included in the regression to test if poor health leads to low income: gender, age, marital status, parental status, self-rated health, employment status, and health insurance coverage (detailed information on how those variables were defined can be found in the Appendix).

It would have been useful to include information on the Aboriginal person or recent immigrant statuses in the models as those characteristics are highly correlated with income and health outcomes, unfortunately there were not enough observations in the samples to do so. Variables providing information on traumas experienced during childhood and on the health history of close relatives, such as mother, father and siblings, were included in the initial models but the associated coefficients turned out to be statistically insignificant, and were therefore dropped.

The reader should note that: 1) the only results that are presented and discussed in the following sections are those that are statistically significant at least at point 0.05 level of probability; 2) predicted probabilities, not odds ratios are reported in this paper as they are easier to interpret. ${ }^{3}$

CSP 2010, 37.1-2: 25-52 
Logistic regression results (Tables 4 and 5) indicate that being persistently poor increases the probability of experiencing deterioration in health to the same extent as being in poor health increases the probability of becoming poor (by 5.7 to $5.8 \mathrm{pp}$ ). However, being poor for only part of the period considered (at most two cycles) appears to have a weaker effect (3.1 pp).

Focusing on low income leading to poor health (Table 4) we find, as expected, that age has the largest impact, i.e. as one gets older the probability of becoming ill grows significantly (going from $2.6 \%$ for those aged 18 to 34 , to $7.9 \%$ for those aged 45 to 64 , to $19.9 \%$ for those 65 years and older). The income effect comes second, with the probability of being in poor health in 2004 going from 5.9\% for those who never experienced poverty over 1996 to 2002, to $9.0 \%$ for those who were poor at most two cycles, to $11.7 \%$ for those who were poor over at least three cycles. Smoking and being physically inactive also increase the probability of becoming ill. Contrary to previous research, being married slightly increases the probability of deterioration in health. This last result may be owed to selection bias (see Limitations).

Focusing on poor health leading to low income (Table 5) we find that being weakly employed (especially if it is for prolonged periods of time) and lacking private health insurance coverage have far more important impacts on income than does health on income (they respectively increase the probability of becoming poor by $11.2 \mathrm{pp}$ and $16.4 \mathrm{pp}$ vs. $5.7 \mathrm{pp}$ for health). Results on insurance coverage have to be interpreted with caution since, as was mentioned previously, persistently poor or weakly employed individuals may inadvertently under-report their real health coverage. As was found in other studies on low income, being a woman or being young significantly increase the risk of becoming poor, while being married decreases it (this last result likely reflects higher poverty rates among unattached individuals and lone parents).

\section{Weak Employment and Poor Health}

Explanatory variables included in the regression testing whether weak labour force attachment leads to poor health were: gender; age, marital status, parental status, level of physical activity, smoker or not, and employment status. Correspondingly, variables included in the regression to test if poor health leads to weak labour force attachment were: gender; age, marital status, parental status, level of physical activity, and self-rated health.

Regression results (Tables 6 and 7) show that being in poor health increases the probability of being weakly employed by more than the reverse $(8.9 \mathrm{pp} \text { vs. } 6.6 \mathrm{pp})^{4}$. They also indicate that being persistently little employed, even more than being persistently poor, increases the probability of deterioration in health (6.6 pp vs. $5.8 \mathrm{pp})$. As expected, poor health has a stronger effect on employment status than on income status ( $8.9 \mathrm{pp}$ vs. $5.7 \mathrm{pp}$ ).

CSP 2010, 37.1-2: 25-52 
The Connection between Low Income,

Weak Labour Force Attachment and Poor Health

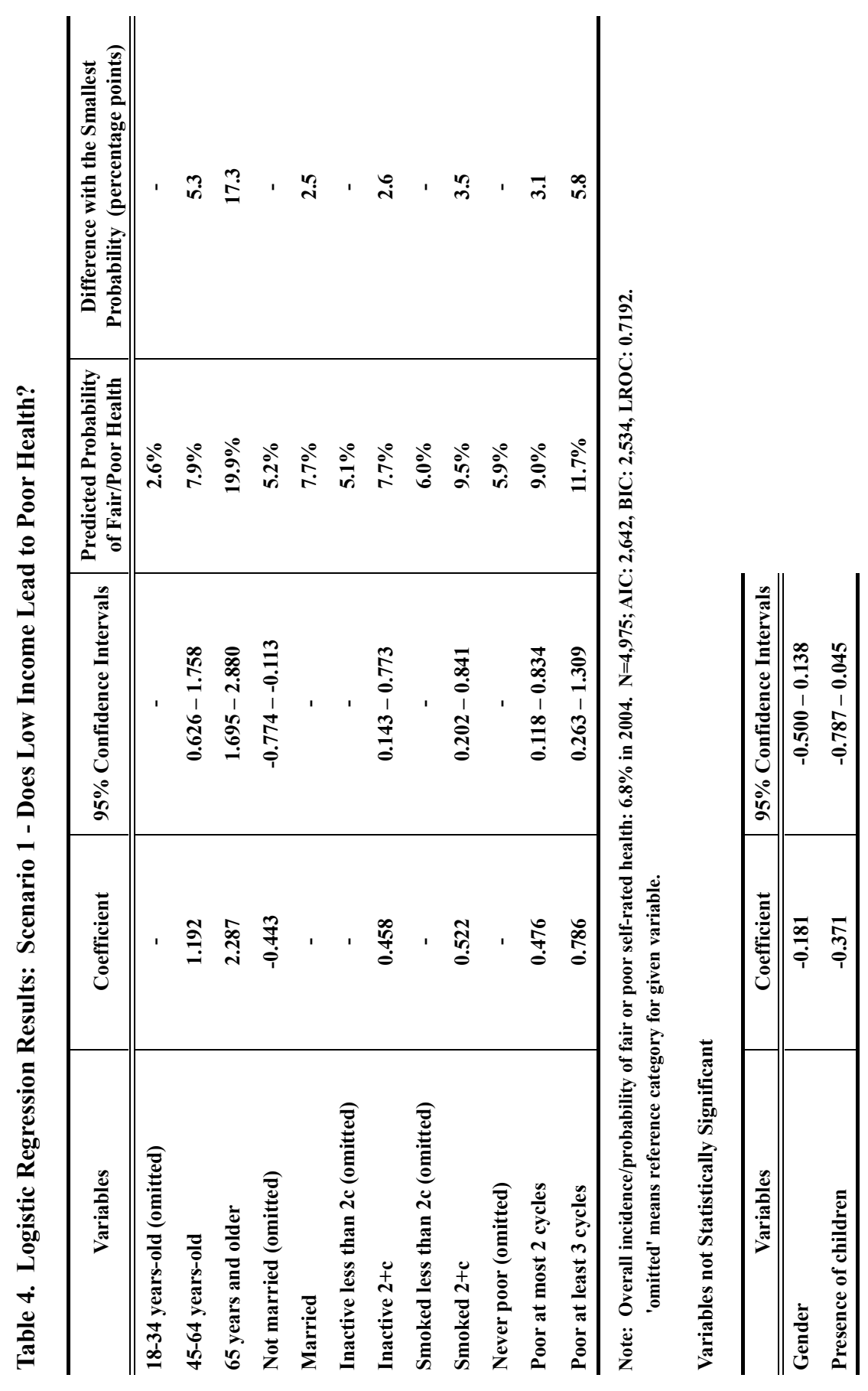

CSP 2010, 37.1-2: 25-52

39 


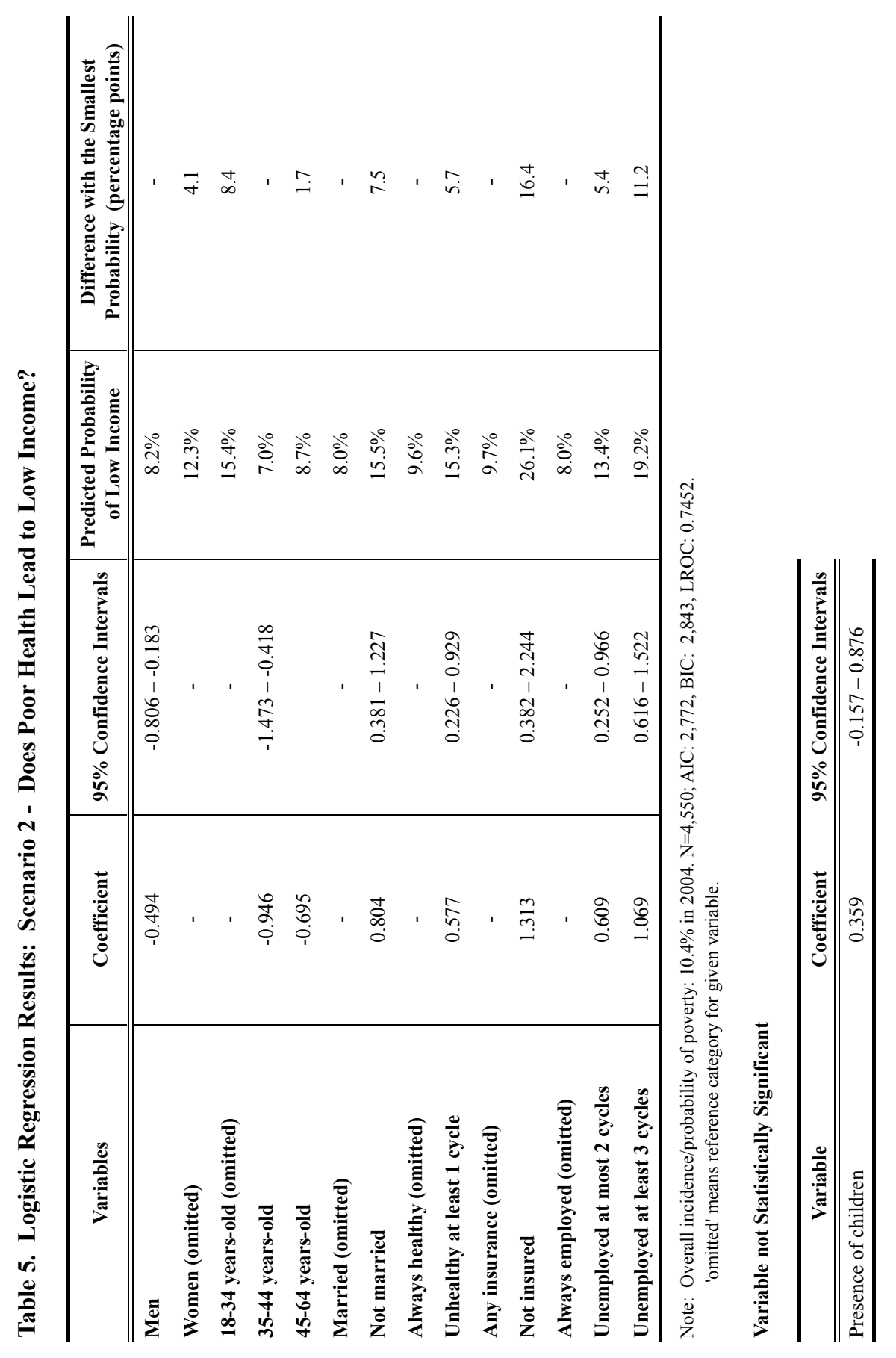

CSP 2010, 37.1-2: 25-52

40 
The Connection between Low Income,

Weak Labour Force Attachment and Poor Health

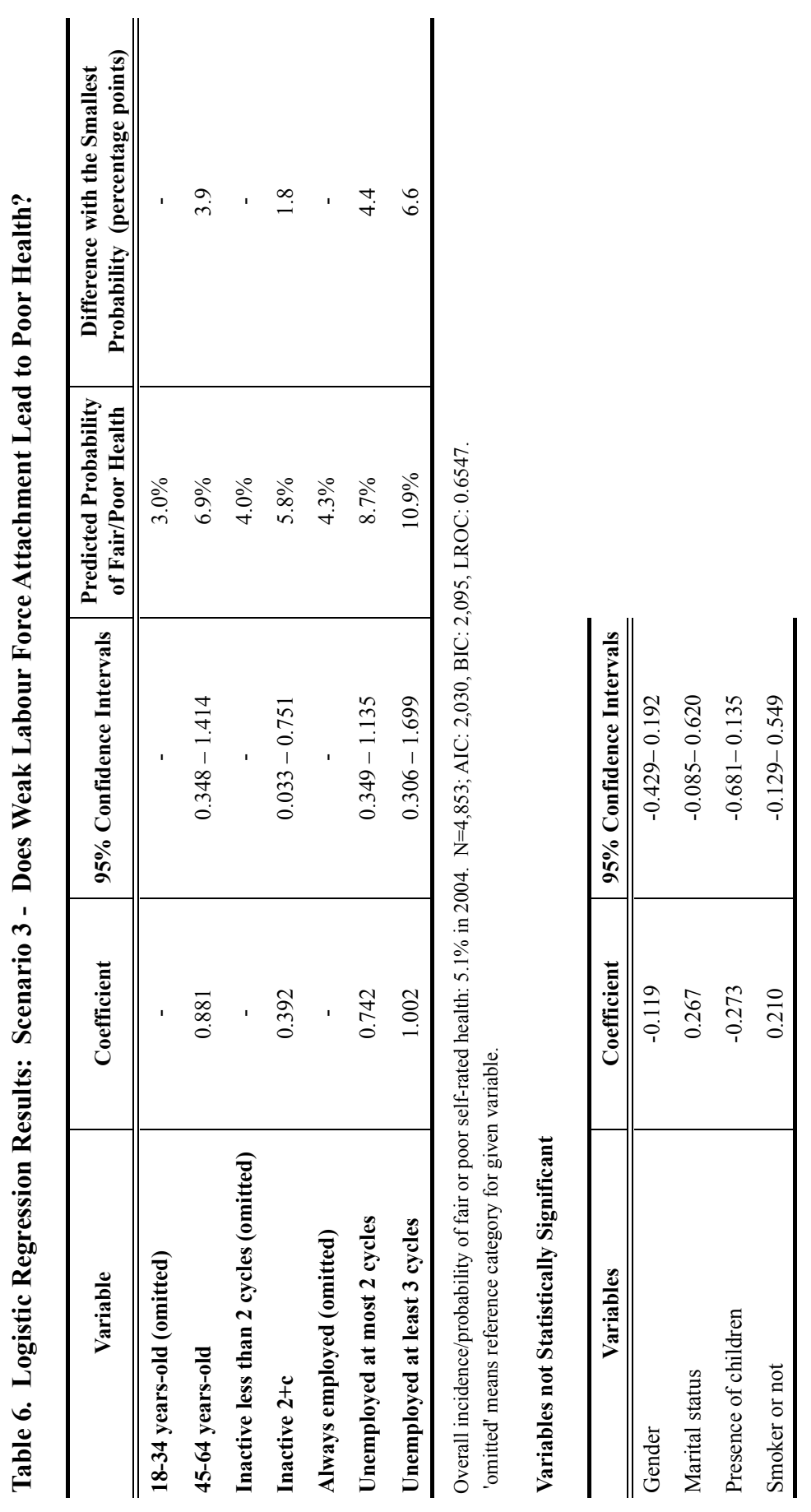

CSP 2010, 37.1-2: 25-52

41 


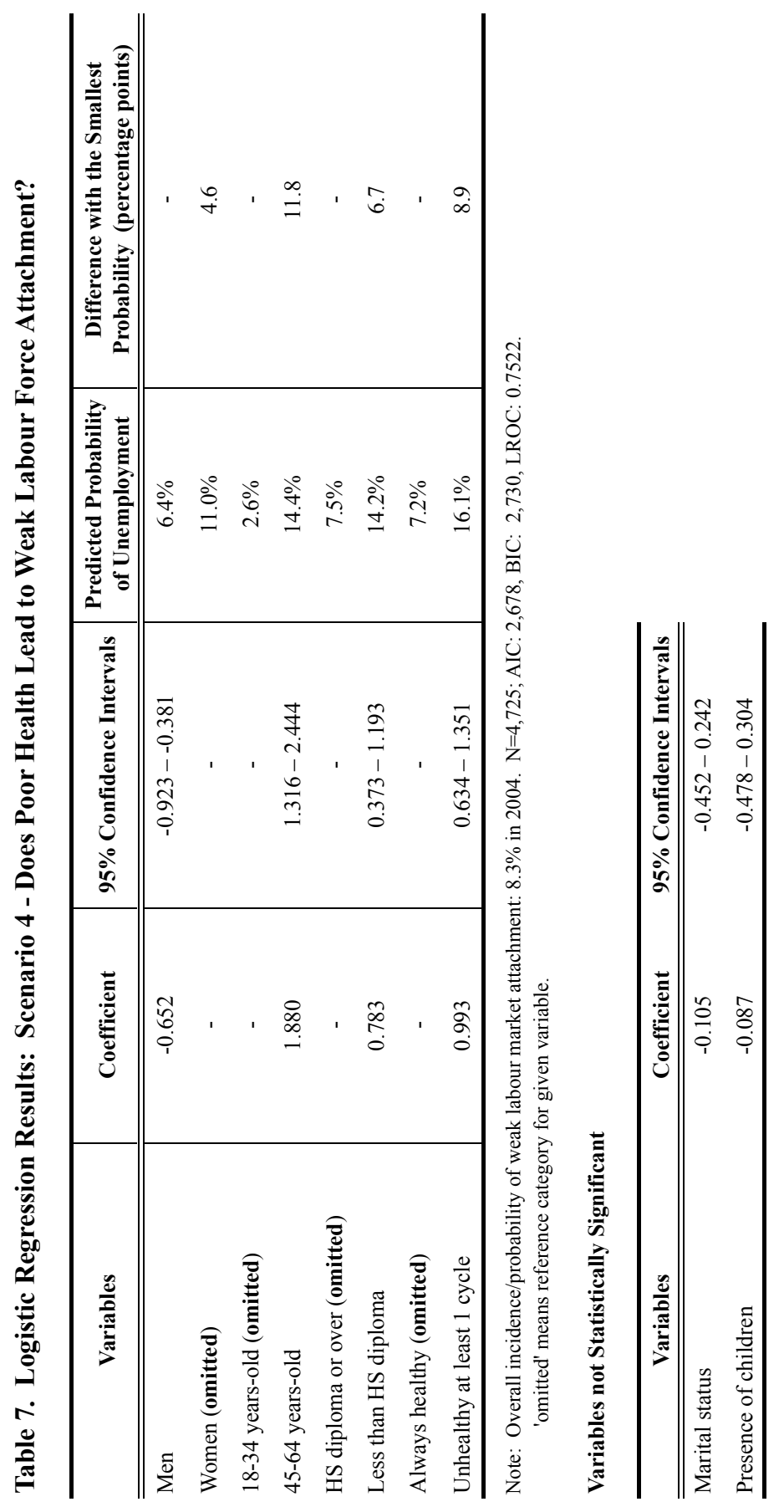

CSP 2010, 37.1-2: 25-52

42 
The Connection between Low Income,

Weak Labour Force Attachment and Poor Health

Focusing on weak labour force attachment leading to poor health (Table 6) we find that employment status had the strongest impact on the probability of reporting poor health in 2004 going from $4.3 \%$ for those who were significantly employed throughout 1996 to 2002 , to $8.7 \%$ for those who were little employed at most two cycles, to $10.9 \%$ for those who were little employed at least three cycles. As found previously, age and physical inactivity increase the probability of deterioration in health, but to a much lesser extent than they did in the regression testing the causal connection between low income and poor health. This may be due to the strong association between age, work limitations status and employment status. Smoking and being married do not significantly affect health in this regression.

Focusing on poor health leading to weak labour force attachment (Table 7) we find that being a woman, at least 45 years old or having less than a highschool diploma also increase the probability of being weakly employed. Those results are consistent with other research findings on unemployment.

\section{Discussion}

Despite the fact that Canada's Health Care System offers minimum coverage to all Canadians independently of their economic situation, socio-economic status matters when it comes to health. This study found that over 1994 to 2004, working-age Canadians who were persistently poor or little employed were a lot more likely to be in poor health than those with higher incomes or a stronger labour force attachment (up to 40 percentage points differences can be observed depending on the outcome considered). Logistic regressions also indicate that persistent poverty leads to poor health as often as the reverse, although persistent unemployment appears to have an even stronger effect.

These findings indicate that policies improving labour force attachment, even more than those improving income, could have important impacts on health. Past studies have showed that the best route to a 'good job' is through education. Reducing high-school drop out rates and making access to higher education easier for all Canadians should, therefore, be efficient ways to keep younger individuals healthy throughout their lives. Such strategies would do little to help individuals that are already in the labour force, however. For this population, better access to training, parental leave or low-cost/quality childcare would be a more adequate response. In the case of immigrants, credential recognition could also help further the employment goal.

Because persistent poverty leads to poor health (although to a slightly lesser degree than unemployment), providing adequate income support to financially disadvantaged populations should also be considered. In particular, investing in policies that 'make work pay', such as the Government of Canada Working Income Tax Benefit, should be favoured as this type of policy 
addresses both income and employment issues at once. Given that budgets devoted to health by all levels of government are quite substantial in Canada, investments in social and economic policies to improve health offer an interesting alternative for example, in 2005, close to $11 \%$ of Canada's GDP went to health while only $5.2 \%$ went to 'other social expenditures' such as oldage pensions, disability benefits, child allowances and credits, employment services, unemployment compensation, housing allowances, etc. ${ }^{5}$. Investing in the social determinants of health also makes sense given the current economic context, where individuals who are otherwise healthy could end up losing their jobs because of the recession which, in turn, might lead them to periods of poverty, and if the situation persists deterioration in health.

Finally, this research indicates that some health outcomes are more closely associated with income status while others are more closely associated with employment status. It is therefore possible that the causal connection between low income, weak labour force attachment and poor health changes with the outcome considered. This issue would clearly deserve further attention.

\section{Limitations}

In this study, NPHS data were used to analyse the connection between low income, weak labour force attachment and poor health. The objective of the NPHS is to document the health of Canadians, not their employment or income progression. Therefore, it is not as easy to target the 'poor' or to quantify attachment to the labour market as it is with the Survey of Labour and Income Dynamics, for example. As well, the NPHS excludes persons living in institutions, the homeless, and residents of some isolated northern communities and Indian reserves, all groups at higher risk of persistent poverty and unemployment, so the results presented in this paper can only underestimate the real extent of health problems among economically vulnerable Canadians.

When conducting logistic regressions some restrictions had to be imposed on the samples. For instance, all samples were restricted to individuals who were in good health and not poor (or significantly employed) in 1994. This means that the target populations that were studied in this paper have a particular profile that may not perfectly mirror the profile of all Canadians.

There is no official measure of poverty in Canada. Poverty is a complex notion that can have various meanings such as lack of social inclusion, being in low-income or being deprived of basic necessities. Consequently, poverty can be measured in many ways. For the sake of efficiency of language as well as to be consistent with international terminology, people living in low income are also referred to as being poor throughout this article.

CSP 2010, 37.1-2: 25-52 
The Connection between Low Income,

Weak Labour Force Attachment and Poor Health

\section{Disclaimer}

The analysis presented in this manuscript is based on data from Statistics Canada. The views expressed in this manuscript are those of the author and do not represent the views of Human Resources and Skills Development Canada, Statistics Canada nor the federal government.

\section{Acknowledgements}

The author would like to thank the reviewers for Canadian Studies in Population for their comments and suggestions for improvement. She would also like to thank Michael Hatfield and Bruce Jamieson, with Human Resources and Skills Development Canada, as well as John Stapleton, with Open Policy, for reviewing the paper rigorously and for providing useful suggestions. Finally, she would like to express her gratitude to Susan Brunet, with Statistics Canada's Research Data Center in Ottawa, for providing technical assistance with the research. Responsibility for any errors rests with the author.

\section{End Notes}

1. Although many researchers have looked at the association between gradients in income and gradients in health, as reported in the Introduction.

2. Note that in all tables presented in this document, the presence of asterisks '***' means that we cannot disclose the information because the sample size is too small (less than 30 observations).

3. See Fleury and Fortin (2006) for a more complete discussion of the advantage of probabilities over odds ratios for interpreting results.

4. Note that the sample was limited to those aged 18-64 in 2002 in the regressions testing the connection between weak work effort and poor health because the correlation between being 65 years and older and being persistently weakly employed was quite high (0.44), reflecting the fact that those who are 65 years and older are much more likely to be

CSP 2010, 37.1-2: 25-52 
retired (i.e. not to work at all) or to work less than other Canadians, which is not, in itself, a problem as long as the person has a decent income.

5. See Adema, W. and M. Ladaique (2009). How expensive is the welfare state?: Gross and Net Indicators in the OECD Social Expenditure Database (SOCX), OECD Social, Employment and Migration Working Papers, No. 92, OECD Publishing. Available at:

http://titania.sourceoecd.org/vl=1876151/cl=20/nw=1rpsv/cgibin/wppdf?file-5ks712h5cg71.pdf.

\section{References}

Australian Bureau of Statistics. 2003. Use of the Kessler Psychological Distress Scale in ABS Health Surveys, Australia, 2001. Information paper. Available at: http://www.abs.gov.au/ausstats/abs@.nsf/papersbytopic?B9ADE.

Buckley, Neil J., Frank T. Denton, A. Leslie Robb and Byron G. Spencer. 2003. Socioeconomic influence on the health of older people: estimates based on two longitudinal surveys, SEDAP Research Paper no. 112. November. Available at: $\underline{h t t p: / / s o c s e r v . m c m a s t e r . c a / s e d a p / p / s e d a p 112 . p d f . ~}$

DesMeules, Marie, Raymond Pong, Claudia Lagacé, Denis Heng, Doug Manuel, Roger Pitblado, Ray Bollman, Judy Guernsey, Arminée Kazanjin and Irene Koren. 2006. How healthy are rural Canadians? An assessment of their health status and health determinants, Canadian Institute for Health Information. September. Available at:

http://secure.cihi.ca/cihiweb/products/rural canadians 2006 report e.pdf

Direction des communications du ministère de la Santé et des Services sociaux du Québec. 2007. Riches de tous nos enfants - La pauvreté et ses répercussions sur la santé des jeunes de moins de 18 ans, Troisième rapport national sur l'état de santé de la population du Québec. Available at: http://intracom.hq-ac.prv/fas-sfa/librarybibliotheque/reports/richesdetous.pdf.

Fleury, Dominique. July 2007. A study of poverty and working poverty among recent immigrants to Canada, Human Resources and Social Development Canada, Working Paper Series. Available at:

http://www.hrsdc.gc.ca/en/publications resources/research/categories/incl usion/2007/sp_680_05_07_e/sp_680_05_07e.pdf. 
The Connection between Low Income,

Weak Labour Force Attachment and Poor Health

Fleury, Dominique, Myriam Fortin and May Luong. 2005. What does it mean to be poor and working? An analysis of the spending patterns and living conditions of working poor families in Canada, Policy Research Initiative Research Papers Series. Available at:

http://policyresearch.gc.ca/page.asp?pagenm=pub wp abs.

Fleury, Dominique and Myriam Fortin. August 2006. When working is not enough to escape poverty: an analysis of Canada's working poor. Human Resources and Social Development Canada, Working Paper Series, available at:

http://www.hrsdc.gc.ca/en/cs/sp/sdc/pkrf/publications/research/SP-63006-06/page00.shtml.

Fortin, Myriam. September 2008. "How (un)healthy are poor working-age Canadians?" Policy Options Politiques 29(8): 71-74.

Fortin, Myriam. 2005. The other face of working poverty. Policy Research Initiative Research Papers Series. Available at:

http://policyresearch.gc.ca/page.asp?pagenm=pub wp abs.

Hatfield, Michael. 2004. "Vulnerability to Persistent Low Income." Horizons $7(2): 19-26$.

Human Resources and Social Development Canada. 2006. Low income in Canada: 2000-2002 using the market basket measure. Available at: http://www.hrsdc.gc.ca/en/cs/sp/sdc/pkrf/publications/research/2002$\underline{000662 / \text { page } 00 . s h t m l}$

Kapsalis, Constantine and Pierre Tourigny (forthcoming). Profiles and transitions of groups most at risk of social exclusion. Human Resources and Social Development Canada, Working Paper Series.

Morris, Evan, David Rosenbluth, Doug Scott, Trish Livingstone, Lisa Lix, Mary McNutt and Felecia Watson. 2005. "To what extent does poor health precede welfare?" Canadian Journal of Public Health 96(3): 201-205.

Mullhaly, John, S. Robert and B. L. Wolfe. 2004. "Health, income and inequality," in Social Inequality. Kathryn Neckerman (ed.), New York, NY: Russell Sage Foundation. Pp. 523-544.

CSP 2010, 37.1-2: 25-52 
Ng, Edward, Russell Wilkins, Jason Pole and Owen B. Adams. 1997. How far to the nearest physician? Statistics Canada Health Reports 8(4): 19-31. Available at: http:/www.statcan.ca/english/freepub/82-003XIE/0049682-003-XIE.pdf.

Orpana, Heather M., Louise Lemyre and Shona Kelly. 2007. "Do stressors explain the association between income and declines in self-rated health? A longitudinal analysis of the National Population Health Survey." Internal Journal of Behavioral Medicine 14(1): 40-47.

Phipps, Shelley. June 2003. The impact of poverty on health - a scan of research literature. Poverty and Health, Canadian Population Health Initiative collected papers. Available at: http://secure.cihi.ca/cihiweb/products/CPHIImpactonPoverty e.pdf.

Piérard, Emmanuelle et al. October 17, 2003. Bootstrapping Made Easy: A Stata ADO File, Mc Master Research Data Centre, Statistics Canada.

Pong, Raymond W. and J. R. Pitblado. 2005. Geographic Distribution of Physicians in Canada: Beyond How Many and Where. Canadian Institute for Health Information. Available at: http://dsppsd.pwgsc.gc.ca/Collection/H118-35-2005E.pdf.

Quebec. 2007. Riches de tous nos enfants - La pauvreté et ses repercussions sur la santé des jeunes de moins de 18 ans. Troisième rapport national sur l'état de santé de la population du Québec. Produit par la Direction des communications du ministère de la Santé et des Services sociaux du Québec, http://intracom.hq-ac.prv/fas-sfa/librarybibiotheque/reports/richesdetous.pdf.

Raphael, Dennis. 2001. "Increasing poverty threatens the health of all Canadians." Canadian Family Physician 47: 1703-1706.

Raphael, Dennis. 2002. Poverty, income inequality, and health in Canada, The CSJ foundation for research and education.

Raphael, Dennis. 2007. Poverty and policy in Canada: implications for health and quality of life, Toronto: Canadian Scholars' Press.

Raphael, Dennis. 2003. "When social policy is health policy - Why increasing poverty and low income threatens Canadians' health and health care system." Canadian Review of Social Policy 51: 9-28. Available at: http://dawn.thot.net/docs/dennisraphael1.doc. 
The Connection between Low Income, Weak Labour Force Attachment and Poor Health

Statistics Canada. Table 2 Social Security Expenditures by Welfare Program and Total Health and Education Expenditures, Canada, 1978-79 to 2002-03. Available at:

http://www.hrsdc.gc.ca/en/cs/sp/sdc/socpol/tables/table2.shtml.

Toronto Public Health. 2008. The Unequal City: Income and Health Inequalities in Toronto. Available at:

http://www.toronto.ca/health/map/inequalities.htm.

Wilkins, Russell, Michael Tjepkema, Cameron Mustard and Robert Choinière. 2008. "The Canadian census mortality follow-up study, 1991 through 2002." Statistics Canada Health Reports, 19(3). Available at:

http://www.statcan.ca/english/freepub/82-003XIE/2008003/article/10681-en.pdf.

Williamson, Deana L. and Linda Reutter. December, 1999. "Defining and measuring poverty: implications for the health of Canadians." Health Promotion International, 14(4): 355-364. Available at: http://heapro.oxfordjournals.org/cgi/reprint/14/4/355.

Wolfson, Michael, Geoff Rowe, Jane F. Gentleman and Monica Tomiak. 1993. "Career earnings and death: A longitudinal analysis of older Canadian men.” Journal of Gerontology: Social Sciences 48(4): S167-S179. 
Appendix

Definition of Variables using Data from NPHS Cycles 1-6

\begin{tabular}{|c|c|}
\hline Variable & Definition \\
\hline Poor04 & $\begin{array}{l}\text { Ratio of household income to relevant Low Income Cut Off (LICO) was in deciles } 1 \text { or } 2 \text { of } \\
\text { variable INCADRCA in } 2004 \text { (1); Ratio of household income to relevant LICO was in deciles } 3 \\
\text { to } 8 \text { of variable INCADRCA in } 2004 \text { (0). (Details on the choice of the low-income threshold } \\
\text { are presented at the end of this table). }\end{array}$ \\
\hline Weakemp04 & $\begin{array}{l}\text { Individual was weakly employed in } 2004 \text { (1); Individual was significantly employed in } 2004 \text {, } \\
\text { i.e. the individual was working full-time or was unemployed but was looking for work the } \\
\text { remaining time (0). (By 'weakly employed' we mean that the individual was: 1) employed part } \\
\text { of the year but was not looking for work the remaining time, or 2) was unemployed part of the } \\
\text { year (or all year) and also not looking for work the remaining time, or 3) was inactive all year). }\end{array}$ \\
\hline Poorhealth04 & $\begin{array}{l}\text { Respondent rated own health as being fair or poor in } 2004 \text { (1); Respondent rated own health as } \\
\text { being good, very good or excellent in } 2004(0)\end{array}$ \\
\hline Gender & Male (1); Female (0) \\
\hline Age 18-34 & Respondents aged $18-34$ years old in $2002(1)$; all other ages $(0)$ \\
\hline Age35-44 & Respondents aged $35-44$ years old in $2002(1)$; all other ages $(0)$ \\
\hline Age45-64 & Respondents aged 45-64 years old in $2002(1)$; all other ages $(0)$ \\
\hline Age65+ & Respondents aged 65 years or older in $2002(1)$; all other ages $(0)$ \\
\hline Married02 & $\begin{array}{l}\text { Respondent was NOT (married or living common law) in } 2002 \text { (1); Respondent was married or } \\
\text { living common law in } 2002(0) \text {. }\end{array}$ \\
\hline Parent02 & Respondent did NOT have children in $2002(1)$; Respondent had children in $2002(0)$ \\
\hline Inactive96-02 & $\begin{array}{l}\text { Respondent was physically inactive at least two cycles over 1996-2002 (1); Respondent was } \\
\text { physically inactive less than two cycles over 1996-2002 (0). }\end{array}$ \\
\hline Smoke96-02 & $\begin{array}{l}\text { Respondent smoked at least two cycles over 1996-2002 (1); Respondent smoked less than two } \\
\text { cycles over 1996-2002 (0). }\end{array}$ \\
\hline Insured96-02 & $\begin{array}{l}\text { Respondent had any type of private health insurance in at least one cycle over } 1996 \text { to } 2002(0) \\
\text { Respondent did not have any type of health insurance coverage in any of the cycles (1). }\end{array}$ \\
\hline Poor96-02 & $\begin{array}{l}\text { Respondent was never poor over 1996-2002 (0); Respondent was poor exactly one or two } \\
\text { cycles over 1996-2002 (1); Respondent was poor exactly three or four cycles over 1996-2002 } \\
(2) \text {. }\end{array}$ \\
\hline Weakemp96-02 & $\begin{array}{l}\text { Respondent was significantly employed all cycles between } 1996 \text { and } 2002 \text { (0); Respondent was } \\
\text { weakly employed exactly one or two cycles between } 1996 \text { and } 2002 \text { (1); Respondent was } \\
\text { weakly employed exactly three or four cycles between } 1996 \text { and } 2002 \text { (2). }\end{array}$ \\
\hline Poorhealth96-02 & $\begin{array}{l}\text { Respondent rated own health as being good, very good or excellent in all cycles between } 1996 \\
\text { and } 2002(0) \text {; Respondent rated own health as being fair or poor in at least one cycle between } \\
1996 \text { and } 2002 \text { (1). }\end{array}$ \\
\hline
\end{tabular}

CSP 2010, 37.1-2: 25-52 
The Connection between Low Income,

Weak Labour Force Attachment and Poor Health

\section{Appendix (Continued)}

\section{Identification of those in low income}

The identification of individuals in low income using data from Statistics Canada's Survey of Labour and Income Dynamics (SLID) is rather straightforward as the SLID include flag variables to indicate whether an individual has, or not, a family income below a before or after-tax low-income cut off (or LICO). The NPHS does not have a flag to indicate who is in low income or not.

Instead, it includes variables that get to the relative income situation of Canadians.

Unfortunately, these variables are not easy to interpret. In order to make a connection between them and the low-income status of individuals, the following methodology was developed using SLID data.

\section{Operations to re-create INCADRCA using SLID data}

Following Statistics Canada's methodology outlined in Documentation for the Derived Variables and the Constant Longitudinal Variables (November 2006), the following three operations were performed, using SLID data, to re-create INCADRCA ${ }^{\mathrm{a}}$ :

1.) Calculation of an individual ratio $=(\text { household income } / \text { relevant after-tax LICO })^{b}$;

2.) Calculation of an adjusted ratio $=(\text { ratio/ratio max })^{\text {c }}$;

3.) Separation of the weighted population in deciles, according to their adjusted ratios ${ }^{\mathrm{d}}$.

\section{Identification of those in low income for each decile}

Once the variables were re-created, the proportion of the population that actually has a low family income in each decile was identified (using the after-tax LICO as the measure of low income). The result of these operations is presented in the Appendix table $\mathrm{e}^{\mathrm{e}}$. This table shows that:

1.) Whatever the year considered, all individuals that fall in the first decile of variable INCADRCA consistently have a low family income according to the after-tax LICO;

2.) The proportion of individuals falling into the second decile of variable INCADRCA that actually has a low family income varies a lot from year to year. This proportion was relatively high in the early 1990 s, decreasing rapidly nearing 2000 . 


\section{Appendix (Continued) \\ Proportion of Individuals whose Income falls in any of the First or Second Decile of the Ratio of Household Income to LICO that actually has a Low Family Income}

\begin{tabular}{lll}
\hline Cycle & $\begin{array}{c}\text { Proportion of the population that falls into } \\
\text { the first decile that is actually 'poor' } \\
\text { (according to the after-tax LICO) }\end{array}$ & $\begin{array}{c}\text { Proportion of the population that falls into } \\
\text { the second decile that is actually 'poor' } \\
\text { (according to the after-tax LICO) }\end{array}$ \\
\hline \hline 1994 & $100 \%$ & $35 \%$ \\
1996 & $100 \%$ & $41 \%$ \\
1998 & $100 \%$ & $24 \%$ \\
2000 & $100 \%$ & $12 \%$ \\
2002 & $100 \%$ & $4 \%$ \\
2004 & $100 \%$ & $2 \%$ \\
\hline
\end{tabular}

These results could signal that the 'poor' should be defined as those whose income falls into the first decile of variable INCADRCA only. However, we decided to broaden this definition to include individuals whose income falls into the first two deciles of this variable for the following reasons:

1. Studies on the income dynamics of the poor show that if those who are poor move out of low income quickly, they can also fall back into it rapidly. For instance, Fleuryu and Fortin (2006) show that close to $41 \%$ of those who were working poor in 1996 exited poverty in 1997 . However, over 1996 to 2001 , they spent an average three years out of six in low income. Furthermore, even after definitively existing low income, the average income of former working poor persons remained signficantly below that of the rest of the population ${ }^{\mathrm{f} .}$ All this indicates that the 'poor' and 'near poor', although not identical, could overlap in many instances.

2. Studies on the determinants of health clearly show that health status improves as income increases, i.e., not only those in low income but also those near low income have worse health outcomes than those with higher incomes.

3. Sample size can become an issue whe doing in-depth analyses of relatively small populations (as in the case for low-income persons at higher risk of persistent poverty). Expanding the sample size will allow for more in-depth analyses.

4. Finally, as mentioned in Raphael (2007), "Canadian researchers usually examine individuals' level of income and identify those at the bottom $20 \%$ of the distribution or some similar variant as living on low incomes or living in poverty." (p. 206) Consequently, identifying the poor as those whose income falls into any of the first deciles of variable INCADRCA is in line with what other health researchers have done so far.

Notes:

a. Note that this procedure was recognized as being 'appropriate' by France Bilocq, Chief NPHS Survey with Statistics Canada in 2007, although Mrs. Bilocq noted that no similar analysis had been done by Statistics Canada.

b. When the household income was negative the ratio was set to 0 . Individuals were then sorted out by household income to ensure that those with very negative incomes would show up first in the list of individuals with a ratio of 0 .

c. The ratio max was set at 10 (and everybody who had a ratio higher than 10 was assigned a value of 10) because very few individuals had a ratio of 10 and over, i.e., were 'outliers'.

d. The adjusted ratios were sorted by ascending order before setting the deciles. The deciles were dervied for the weighted population.

e. Only the results for the first and second deciles are shown as other deciles had very little proportions (if any) of individuals in low income in any year. 